\title{
Enhance your skills
}

Rare books, technology, and

science will be topics of five New

Orleans preconferences

$\mathbf{A}$ CRL will offer five preconferences prior to the ALA Annual Conference in New Orleans this summer. Details about each follow.

\section{4th rare books preconference}

"Mainstream or Margin? How Others View Special Collections" is the title of ACRL's Rare Books and Manuscripts Section's (RBMS) 34th preconference to be held June 22-25, 1993, at the Omni Royal Orleans Hotel in New Orleans.

Preconference program chair Pat Bozeman says, "A multifaceted vision of who and what we are-as well as a vision of what we wish special collections to become-is necessary if we are to anticipate and respond to the changes and challenges brought on by institutional restructuring, shrinking resources, and the shifting patterns in collection use."

Speakers. To this end a diverse group of speakers have been chosen to address the questions of "mainstream" and/or "margin" in a challenging, provocative, and creative way. Speakers include: Betty Bengtson, director, University of Washington Libraries; Daniel Bradbury, director, Kansas City Public Library; John T. Casteen III, president, University of Virginia; Stanley Chodorow, associate vice-chancellor of academic planning and dean of arts and humanities, University of California, San Diego; Judith Goldstein, anthropologist, Vassar College; Joan Gotwals, vice-provost and director of libraries, Emory University; William Jones, assistant university librarian for collections development and information services, University of Illinois at Chicago; Brian Schottaender, assistant university librarian for technical services, University Research Library, UCLA; Steven Watson, independent scholar and author, New York City; and David Zeidberg, head of special collections, University Research Library, UCLA.
Plenary sessions. The plenary sessions will be complemented by a series of continuing education seminars addressing such topics as career building in special collections; cataloging Latin materials; collection-level cataloging; electronic texts; gay and lesbian studies and use of special collections; marketing our collections and ourselves; Slavic and Eastern European books in American libraries; strategies for downsizing special collections: advantages/ disadvantages of deaccessioning, reformatting, and off-site storage; and undergraduate use of special collections.

Registration. The registration fee for the three-day preconference is $\$ 150$ for ACRL members and $\$ 200$ for nonmembers; the deadline for registration is May 10. Written cancellations will be honored until June 4 , subject to a $\$ 45$ cancellation fee. In addition to the plenary and seminar sessions, preconference registrants will enjoy an opening reception at the Historic New Orleans Collection, an evening of tours, Cajun food, and lively musical entertainment at Destrehan Plantation (one of the older plantation houses in the Lower Mississippi Valley), and a reception and tours at the Howard-Tilton Memorial Library, Tulane University. Historic architectural and literary walking tours of New Orleans will also be available on the afternoon of June 22 .

Lodging. The Omni Royal Orleans Hotel, in the heart of the French Quarter, will serve as the preconference hotel at the special rate for $\$ 90$ for single, double, and twin rooms. It is an ALA Annual Conference hotel. For those wishing to stay at the Omni for AlA, separate registration is necessary through ALA Housing due to a differential in preconference and Annual Conference rates. Alternative housing is also available for the preconference in traditional residence halls on the campus of Tulane University. Residence hall double occupancy is $\$ 19$ per person, per night, and single occupancy is $\$ 25$ per night. Apartment housing is also available on the Tulane campus. The charge for four persons per apartment is $\$ 35$ a person, per night, and for two persons the charge is $\$ 47.50$ a person, per night. All Tulane housing is subject to a $\$ 5$ 
registration fee and registrants must make their own arrangements with the Tulane University Housing Office.

Brochure. A brochure describing the preconference, including a registration form, will be mailed to all RBMS members around March 1. If you would like to receive a brochure contact the ACRL office at (800) 545-2433 ext. 2522 or 3248 or fax: (312) $280-2520$

\section{Science Reference Service}

"Science Reference Service: An Introduction for the General Reference Librarian" is the title of ACRL's Science and Technology Section's (STS) full-day preconference to be held June 25, 1993.

Audience. This program is designed for the general reference librarian. Update your knowledge of science and technology resources and enhance your skills in answering questions in these disciplines. Review the nature of scientific research and the publication process. Experts lead you through the literature in life sciences, physical sciences, and applied sciences. Explore CD-ROM and online databases. Vendor receptions and product demonstrations conclude the preconference.

Speakers. Introduction by Thomas Kirk, ACRL president-elect, college librarian, Berea College; "What Young Scientists Bring to the Library: What Nonscientists in the Library Can Do to Help Them," keynote address, Tony Stankus, science librarian, College of the Holy Cross; "CD-ROM and Online Sources and Strategies," Robin Raquet, science librarian, Trinity University; physical science sources, Arleen Somerville, physical sciences librarian, University of Rochester; applied sciences sources," LeAnn Weller, engineering librarian, University of Kansas; life sciences sources, Christina Peterson, life and health sciences librarian, San Jose State University.

Registration. The registration fee is $\$ 120$ for ACRL members, $\$ 155$ for ALA members, and $\$ 195$ for non-ALA members. The deadline for registration is May $17,1993$.

\section{Creating the virtual library}

"Creating the Virtual Library" is the title of ACRL's Educational and Behavioral Sciences Section's (EBSS) half-day preconference to be held June $25,1993$.

Audience. This program is for librarians and administrators or computer-center professionals interested in expanding the boundaries of their libraries through the use of information technology. Academic libraries are experiencing a transformation with the evolution of the virtual library-a system by which users may connect transparently to remote libraries and databases, using the OPAC as a gateway. The introduction will present this vision and its impact on library organization and services. Four librarians actively involved in a cooperative networking project will share global issues and practical information. A professor who teaches through distance education will present new opportunities for academic libraries.

Speakers. "What Is the Virtual Library?" Laverna Saunders, assistant university librarian for technical services, University of Nevada, Las Vegas; "Administrative and Systems Decisions," Myoung-ja Lee Kwon, associate dean of libraries, University of Nevada, Las Vegas, and Carol Parkhurst, assistant university librarian for systems and technical services, University of Nevada, Reno; "Academic Issues and the Virtual University," John Cochenour, assistant professor of instructional technology, University of Wyoming; "Training Staff and Users to Navigate the Virtual Library," James McPhee, head of library instruction, University of Nevada, Las Vegas, and Betty Glass, instructional services librarian, University of Nevada, Reno.

Registration. The registration fee is $\$ 100$ for ACRL members, $\$ 140$ for ALA members, and $\$ 190$ for non-ALA members. The deadline for registration is May $17,1993$.

\section{Internet tools and services}

"Navigating and Navigators: Research and Development in Navigational Tools \& Services for the Internet" is the title of this full-day preconference cosponsored by the Coalition for Networked Information to be held June 25, 1993.

Audience. This program is for anyone responsible for library/information resources and services in academic, public, or school libraries. It will focus on contact with inventors of new technologies for navigation of networks and with those responsible for planning user services in the networked environment. Emphasis will be on the design of such technologies and systems as Gopher, Archie, WAIS, and Netfind; on issues such as user needs and data elements for records; and on initiatives such as the Coalition's TopNode.

Speakers. The preconference will be led by George Brett, director, Clearinghouse for Networked Information Discovery \& Retrieval, and Peggy Seiden, head of public services, 
Skidmore College-coleaders of the coalition's Working Group on Directories and Resource Information Services. A wide variety of other speakers will also make presentations and be available for informal discussions.

Registration. The registration fee is $\$ 150$ for ACRL members, $\$ 185$ for ALA members, and $\$ 215$ for non-ALA members (lunch is included). The deadline for registration is May 17, 1993.

\section{Leadership and rechnological change}

"Leadership and Technological Change: A Call to Action Now" is the title of this joint technology full-day preconference cosponsored by ACRL, the Library Administration and Management Association (LAMA), and the Library Information and Technology Association (LITA). It will be held June 25, 1993.

Audience. The audience for this preconference is directors, managers, library leaders or leaders-to-be needing introductory technological information. If technology in your library is not greatly advanced, this preconference is for you. It offers strategies and solutions for making the vision of technology a reality in your library. Move your library into the 21 st century. Technology is in your future whether your library is large, small, or midsized.

Speakers. Speakers Carol Hildebrand, Eugene Public Library, and Paul Peters, Coalition for Networked Information, and guided group work will provide direction, techniques, and resources to help you bring technology to your library.

Registration. The registration fee is $\$ 95$ for ACRL/LAMA/LITA members, \$120 for ALA members and for non-ALA members (lunch is included). The deadline for registration is May 17, 1993.

\section{ACRL preconference registration form}

Deadline: May 17, 1993

Note: Please call the ACRL office to request a form for the RBMS preconference.

Please type or print:

Name (as it should appear on your badge)

Title

$\overline{\text { Organizational Name (as it should appear on badge) }}$

Mailing Address

\begin{tabular}{ll}
\hline City & State/Zip \\
\hline Telephone (daytime) & Fax
\end{tabular}

ALA Membership Number

Send registration form with payment to:

ACRL Preconference

50 E. Huron St.

Chicago, IL 60611

or

Fax registration and charge information to:

ACRL Preconference: (312) 280-2520
Select a preconference and circle the fee

non-

ACRL ALA ALA

Preconference member mem. mem.

Science Reference

$\begin{array}{lrrr}\text { Service } & \$ 120 & \$ 155 & \$ 195 \\ \begin{array}{l}\text { The Virtual Library } \\ \begin{array}{l}\text { Navigating the } \\ \text { Internet }\end{array}\end{array} & \$ 100 & \$ 140 & \$ 190 \\ \begin{array}{l}\text { Leadership \& } \\ \text { Technology }\end{array} & \$ 95 & \$ 120 & \$ 120\end{array}$

\section{$\$ 35$ late fee after May 17, 1993}

Total payment: Check enclosed:

or Charge: $\square$ Visa $\square$ MasterCard $\square$ AmEx

Expiration Date

Card Number

Signature

Written cancellations will be honored until June 4 , subject to a $\$ 45$ cancellation fee 